\title{
An assessment of fishing communities around Lake Victoria, Uganda, as potential populations for future HIV vaccine efficacy studies: an observational cohort study
}

Noah Kiwanuka ${ }^{1,3^{*}}$, Juliet Mpendo ${ }^{1}$, Annet Nalutaaya ${ }^{1}$, Matthias Wambuzi ${ }^{1}$, Annet Nanvubya ${ }^{1}$, Paul K Kitandwe', Enoch Muyanja', Julius Ssempiira', Apolo Balyegisawa², and Ali Ssetaala ${ }^{1}$ for the UVRIIIAVI Research Team

\begin{abstract}
Background: An effective HIV vaccine is still elusive. Of the 9 HIV preventive vaccine efficacy trials conducted to-date, only one reported positive results of modest efficacy. More efficacy trials need to be conducted before one or more vaccines are eventually licensed. We assessed the suitability of fishing communities in Uganda for future HIV vaccine efficacy trials.
\end{abstract}

Methods: A community-based cohort study was conducted among a random sample of 2191 participants aged 18-49 years. Data were collected on socio-demographic characteristics, HIV risky behaviors, and willingness to participate in future HIV vaccine trials (WTP). Venous blood was collected for HIV serological testing. Retention/follow rates and HIV incidence rates per 100 person years at-risk (pyar) were estimated. Adjusted prevalence proportion ratios (PPRs) of retention and odds ratios (ORs) of lack of WTP were estimated using log-binomial and logistic regression models respectively.

Results: Overall retention rate was 76.9\% (1685/2191), highest (89\%) among participants who had spent 5+ years in the community and lowest (54.1\%) among those with $<1$ year stay. Significant predictors of retention included tribe/ ethnicity, baseline HIV negative status, and longer than 1 year stay in the community. Overall WTP was 89.1\% (1953/ 2191). Lack of WTP was significantly higher among women than men [adj.OR $=1.51$ ( $95 \% \mathrm{Cl}, 1.14-2.00)]$ and among participants who had stayed in fishing communities for 10 or more years relative to those with less than one year [adj.OR $=1.78(95 \% \mathrm{Cl}, 1.11$ - 2.88)]. Overall HIV incidence rate per 100 pyar was 3.39 (95\% Cl; 2.55 - 4.49). Participants aged 25-29 years had highest incidence rates (4.61 - 7.67/100 pyar) and high retention rates between 78.5 and $83.1 \%$. In a combined analysis of retention and incidence rates participants aged 30+ years had retention rates $~ 80 \%$ but low incidence rates (2.45 - 3.57 per 100 pyar) while those aged 25-29 years had the highest incidence rates (4.61 - 7.67/100 pyar) and retention rates $78.5-83.1 \%$.

Conclusions: There is high HIV incidence, retention and WTP among fishing communities around L. Victoria, Uganda which make these communities appropriate for future HIV prevention efficacy studies including vaccine trials.

Keywords: HIV-1 incidence, Retention, Willingness to participate, Fishing communities, Uganda

\footnotetext{
* Correspondence: nkiwanuka@gmail.com

${ }^{1}$ Uganda Virus Research Institute-International AIDS Vaccine Initiate

HIV Vaccine Program, Entebbe, Uganda

${ }^{3}$ Department of Epidemiology and Biostatistics, College of Health Sciences,

School of Public Health, Makerere University, Kampala, Uganda

Full list of author information is available at the end of the article
} 


\section{Background}

Despite the current proven methods of HIV prevention [1-10], an estimated 2.3 million people worldwide become newly infected with HIV each year. The number of new HIV infections has decreased but is still higher than the number of patients initiating Antiretroviral Therapy (ART) [11]. The development of a safe, effective, and accessible HIV preventive vaccine will greatly complement the current prevention interventions and probably lead to the ultimate control of the HIV pandemic. The discovery of an effective HIV vaccine has multiple challenges including the extensive variability of the virus, an incomplete understanding of the mechanisms for immune protection, and the need to identify and characterize appropriate populations for efficacy clinical trials. One of the critical elements of an HIV vaccine efficacy trials is the identification of populations with adequate rates of new HIV infections who are willing to participate (WTP) and who can be efficiently recruited and retained for the duration of the vaccine trial $[12,13]$.

To date, a few efficacy trials of HIV preventive vaccines have been conducted predominantly in highly selected populations [14-19] and all but one [20] reported lack of efficacy in protecting against HIV infection. Since an effective HIV vaccine still eludes the world, more efficacy trials will need to be conducted before licensure is attained. With a number of HIV vaccine candidates currently under phase I and II trials [21,22], it is prudent to identify and prepare suitable populations for future efficacy trials. We assessed the suitability of fishing communities along Lake Victoria, Uganda, as a potential population for future HIV vaccine efficacy trials. In Uganda, fishing communities together with sex workers and long distance truck drivers have been shown to have high incidence rates [23-27] that are 3-7 times higher than the estimated national general population rate [28]. The high risk profile of fishing communities is attributed to a number of factors including the mobile lifestyle of fishermen [27,29-31], high concentration of drinking and entertainment places, high levels alcohol consumption, transactional sex, multiple sexual partnerships and limited access to prevention and care services [24,27,32-34].

\section{Methods}

\section{Study population and procedures}

Between September 2011 and March 2013, we conducted a community-based cohort study among adults in 8 fishing communities (1 lakeshore and 7 islands) in 3 districts bordering Lake Victoria in central Uganda, a region that is mainly inhabited by people of Baganda tribe/ ethnicity. Detailed study procedures have been previously described [35] but briefly, a random sample of 2200 participants aged 18-49 years resident in fishing communities for at least 6 months prior to baseline enrolment were selected from a community wide census database using Stata 12 (StataCorp, College Station, TX) software. Of the 2200 selected, 2191 provided written informed consent and were enrolled at baseline. Intervieweradministered semi-structured questionnaires were used to collect data on socio-demographic characteristics, HIV risk behaviours, and willingness to participate (WTP) in future HIV vaccine studies. Over $99 \%$ of the questionnaires were administered in Luganda (the most commonly spoken language in the study communities) while others were in English. Two weeks to one month prior to the scheduled follow up visit date, community-based health education meetings were conducted, attended by both participants and non-participants. In addition to education and information sharing, participants were reminded of the impending follow up visit but no individualized contact, mailings, phone calls or written invitations were provided. At each visit, venous blood was collected for HIV-1 serological testing and participants were given free voluntary counseling and testing by certified HIV counselors. HIV infected participants were referred to HIV/AIDS care centres for further management and encouraged to seek care. Individuals in study communities (participants and non-participants) were given free access to HIV prevention services including health education, counseling, treatment of sexually transmitted infections (STIs) and voluntary medical male circumcision. After completion of the study procedures each study participant was reimbursed 5000 Uganda shillings (2 USD) for time and travel. Institutional Review Board approvals were obtained from the Uganda Virus Research Institute's Science and Ethics Committee and the Uganda National Council for Science and Technology.

\section{Laboratory testing}

HIV-1 status was determined by rapid HIV tests performed in the community by certified laboratory technologists and EIA confirmation in the laboratory at Uganda Virus Research Institute. In the rapid HIV testing algorithm blood samples were first tested with Determine HIV assay (Alere Medical Co., Ltd., Chiba, Japan), and if negative, results were reported as negative. Determine ${ }^{\circ}$ positive samples were then tested with HIV $1 / 2$ Stat-Pak $^{\circ}$ assay (Chembio Diagnostic Systems, Inc. Medford, NY, USA), if positive, results were reported as positive. But if negative on Stat-Pak ${ }^{\circ}$, Uni-Gold ${ }^{\mathrm{m}}$ HIV test (Trinity Biotech plc, Bray, Ireland) was used as a tie-breaker. All positive rapid results were confirmed using 2 parallel Enzyme Linked Immuno Sorbent Assay (EIA) tests: Vironostika (HIV Uni-Form II plus 0 microelisa system, Biomerieux, SA, Marcy l'Etoile, France); and Murex HIV1.2.O (Diasorin S.P.A, Dartford, United Kingdom). Concordant EIA positives were taken as positive but discordant EIA results were comfirmed using HIV RNA PCR $\left(\mathrm{COBAS}^{\bullet}\right.$ AmpliPrep/COBAS ${ }^{\ominus}$ TaqMan $^{\bullet}$ HIV-1 Test, 
v2.0 from Roche Molecular Diagnostics, Pleasanton, CA, USA).

\section{Statistical analysis}

To evaluate the suitability of fishing communities as potential populations for future HIV prevention efficacy studies, we assessed absolute HIV incidence, retention and WTP. HIV incidence rates per 100 person years atrisk (pyar) were estimated among initially seronegative participants as the number of seroconversions divided by pyar multiplied by 100 . HIV infection was estimated to have occurred at the midpoint between the last negative and first positive serologic tests. Retention was calculated as the number of participants traced and interviewed at the 12 months visit divided by the number enrolled at baseline. Given the high proportion of retention/follow up (76.9\%) we used log-binomial regression models to estimate unadjusted and adjusted prevalence proportion ratios (PPRs) and corresponding 95\% CIs of factors associated with retention. Since odds ratios give biased estimates of prevalence ratios when the proportion of the outcome is greater than $10 \%$, we used $\log$ binomial regression instead of logistic regression $[36,37]$. The final model on retention included gender, age, tribe, occupation, marital status, and duration of stay in community. WTP was assessed hypothetically given that the study did not involve recruitment and receipt of a vaccine (experimental or licensed). This was done only at the baseline visit and the specific question on WTP was: If you were requested to participate in a research study on an experimental HIV preventive vaccine, would you be willing to join the study as a participant? The responses were willing, not willing, not sure, partner would decide and parent would decide. Only the first 3 got responses and the covariate was dichotomized into willing and not willing; not willing and not sure combined because the frequency of the latter was too small for meaningful analyses. Since we were interested in determining characteristics of fisherfolk that one would address in preparation for efficacy trials of HIV prevention, we modeled unwillingness to participate in HIV vaccine trials as the outcome. With a prevalence of $10.7 \%$, ordinary multivariable logistic regression models were used to determine factors associated with unwillingness to participate in vaccine trials. The final model included sex, occupation, duration of stay in community, and alcohol consumption. In all multivariable models we used empirical variance estimator to estimate robust standard errors accounting for any potential correlation at household level (where more than 1 participant from a given household were selected) [38]. Inclusion of variables in multivariable models was based on biological plausibility and a bivariate statistical significance at an alpha $(\alpha)$ of $<0.15$ but statistical significance was determined by $\alpha<0.05$. All regression models were constructed using stepwise logical model building method [39] and statistical analyses were performed using Stata ${ }^{\circ}$ 12 (StataCorp, College Station, TX) software. Analyses involved participants that were HIV negative at baseline and hence at risk of infection.

\section{Results}

\section{Participant retention}

Table 1 shows absolute retention rates, and unadjusted and adjusted prevalence ratios (PRs) of factors associated with retention in fishing communities around Lake Victoria, Uganda. Of the 2191 participants enrolled at baseline, 1685 were interviewed at the 12 months visit giving an overall retention rate of $76.9 \%$. The highest retention rate of $89 \%$ was seen in participants who had spent 5 or more years in fishing communities. Retention rates of $80 \%$ or more were observed in farming occupation $(85.4 \%)$, Baganda tribe $(80.9 \%)$, married monogamous (80.5\%), HIV negative at baseline (80.2\%), and being aged 30 or more years $(80.6 \%$ for $30-39$ years and $83.7 \%$ among $40-49$ years). The lowest retention rate of $54.1 \%$ was observed among participants who at baseline had spent less than a year in fishing communities. At bivariate analysis, retention was significantly lower among participants aged 18-24 years, non-Baganda, bar/hotel/ restaurant workers, single never married, baseline HIV positive, and those who had spent less than a year in the fishing communities. Retention did not statistically differ by sex, age, education status, or religion but adjusted differences were observed according to ethnicity, marital status, occupation, duration of stay in the community, and baseline HIV sero-status (Table 1). Retention was significantly higher among the Baganda ethnic group (adj.PPR $=1.07 ; 95 \%$ CI, 1.03 - 1.12), HIV negatives (adj. $\mathrm{PRR}=1.19 ; 95 \% \mathrm{CI}, 1.13-1.27$ ), those not currently married but previously married (adj.PRR $=1.10$; 95\% CI, 1.01 - 1.18), and among those who had spent more than 1 year in the community at the time of enrolment. Compared to participants with less than 1 year of stay in the community, adjusted PRRs of retention were 1.34 (95\% CI 1.21 - 1.48) for 1 to 4 years, 1.57 (95\% CI, 1.43 1.73) for 5 to 10 years, and 1.59 (95\% CI, 1.44 - 1.76) for more than 10 years of stay in fishing communities.

The overall HIV incidence rate was $3.39 / 100$ pyar (95\% CI; 2.55 - 4.49). We estimated retention rates and absolute HIV incidence rates by a combination of selected risk factors so as to assess potential characteristics that would maximize both retention and incidence in case of targeted enrollment in efficacy studies in this population (Table 2). HIV rates presented in Table 2 are absolute risks that apply to specific groups of single of combined risk factors and are not comparative. Participants aged 30 or more years tended to have 
Table 1 Proportions and prevalence proportion ratios (PPRs) of retention in a cohort of fishing communities around Lake Victoria, Uganda

\begin{tabular}{|c|c|c|c|c|}
\hline & Retention rate (12 months) & Prevalence prop & tios of retention & \\
\hline & $\%$ (No/enrolled) & $\begin{array}{l}\text { Crude } \\
(95 \% \mathrm{Cl})\end{array}$ & $\begin{array}{l}\text { Adjusted } \\
(95 \% \mathrm{Cl})\end{array}$ & P-value \\
\hline All Participants & $80.2(1289 / 1607)$ & & & \\
\hline Sex & & & & \\
\hline Male & $79.6(697 / 876)$ & 1 (Ref) & 1 (Ref) & \\
\hline Female & $81.0(592 / 731)$ & $1.02(0.97-1.07)$ & $1.05(0.99-1.11)$ & 0.074 \\
\hline Age at enrolment (yeal & & & & \\
\hline $18-24$ & $72.8(366 / 503)^{+\dagger}$ & 1 (Ref) & 1 (Ref) & \\
\hline $25-29$ & $79.8(328 / 411)$ & $1.10(1.02-1.18)$ & $1.00(0.93-1.07)$ & 0.933 \\
\hline 30-39 & $86.1(432 / 502)$ & $1.18(1.11-1.26)$ & $1.04(0.97-1.11)$ & 0.273 \\
\hline 40-49 & $85.3(163 / 191)$ & $1.17(1.08-1.27)$ & $1.00(0.92-1.09)$ & 0.953 \\
\hline Highest Education lev & & & & \\
\hline None & $80.4(90 / 112)$ & 1 (Ref) & - & \\
\hline Primary & $79.4(734 / 924)$ & $0.99(0.90-1.09)$ & - & \\
\hline Post primary & $81.3(462 / 568)$ & $1.01(0.92-1.12)$ & - & \\
\hline Religion & & & & \\
\hline Pentecostal/Evangelical & $82.9(131 / 158)$ & 1 (Ref) & - & \\
\hline Roman Catholic & $81.6(507 / 621)$ & $0.98(0.91-1.07)$ & - & \\
\hline Protestant/Anglican & $76.7(342 / 446)$ & $0.92(0.85-1.01)$ & - & \\
\hline Moslem & $80.4(263 / 327)$ & $0.97(0.89-1.06)$ & - & \\
\hline Other" & $83.6(46 / 55)$ & $1.01(0.88-1.16)$ & - & \\
\hline Ethnicity/tribe & & & & \\
\hline Non-Muganda & $76.9(681 / 885)^{t^{+\dagger}}$ & 1 (Ref) & 1 (Ref) & \\
\hline Muganda & $84.2(608 / 722)$ & $1.09(1.04-1.15)$ & $1.06(1.01-1.11)$ & 0.021 \\
\hline Occupation & & & & \\
\hline Fishing/Fishing related & $80.5(648 / 805)$ & 1 (Ref) & 1 (Ref) & \\
\hline Trade/Business & $81.2(135 / 165)$ & $1.02(0.94-1.10)$ & $0.96(0.89-1.04)$ & 0.382 \\
\hline Bar/Lodge/Restaurant & $75.9(123 / 162)$ & $0.94(0.86-1.03)$ & $0.95(0.87-1.05)$ & 0.326 \\
\hline Farming & $86.2(75 / 87)$ & $1.07(0.98-1.17)$ & $1.00(0.92-1.10)$ & 0.870 \\
\hline Housewife & $78.3(101 / 129)$ & $0.97(0.88-1.07)$ & $0.93(0.84-1.03)$ & 0.194 \\
\hline Others $^{\dagger}$ & $79.9(207 / 259)$ & $0.99(0.92-1.06)$ & $0.98(0.92-1.05)$ & 0.667 \\
\hline Marital status & & & & \\
\hline Never married & $70.2(214 / 305)^{\dagger+}$ & 1 (Ref) & 1 (Ref) & \\
\hline Not currently married & $79.7(263 / 330)$ & $1.14(1.04-1.24)$ & $1.03(0.93-1.13)$ & 0.570 \\
\hline Married monogamous & $83.3(575 / 690)$ & $1.19(1.09-1.29)$ & $1.08(0.99-1.18)$ & 0.064 \\
\hline Married polygamous & $80.4(237 / 282)$ & $1.20(1.09-1.31)$ & $1.07(0.97-1.17)$ & 0.169 \\
\hline Duration in communit & & & & \\
\hline Less than 1 & $58.3(175 / 300)$ & 1 (Ref) & 1 (Ref) & \\
\hline 1 to 4 & $77.6(464 / 598)$ & $1.33(1.20-1.48)$ & $1.31(1.17-1.45)$ & $<0.0001$ \\
\hline 5 to 10 & $90.9(440 / 484)$ & $1.56(1.41-1.72)$ & $1.50(1.35-1.66)$ & $<0.0001$ \\
\hline More than 10 & $93.3(210 / 225)$ & $1.60(1.44-1.77)$ & $1.54(1.39-1.72)$ & $<0.0001$ \\
\hline
\end{tabular}

${ }^{*} 3$ missing education, "Seventh Day Advent/Traditionist ${ }^{\dagger}$ Construction/Mechanic/Government/Clerical,${ }^{+1}$ Statistically significant at $\mathrm{p}<0.05$ during bivariate analysis. 
Table 2 Retention rates and absolute HIV incidence rates by selected risk factors

\begin{tabular}{|c|c|c|c|}
\hline \multirow[t]{2}{*}{ Characteristic } & \multicolumn{2}{|c|}{ Retention at 12 months } & \multirow{2}{*}{$\begin{array}{l}\text { Absolute HIV risk } \\
\text { Rate/100 pyar }(95 \% \mathrm{Cl}\end{array}$} \\
\hline & Percent & (Followed/enrolled) & \\
\hline All participants & $76.9 \%$ & $(1685 / 2191)$ & $3.39(2.55-4.49)$ \\
\hline \multicolumn{4}{|l|}{ Age at enrolment (years) } \\
\hline $30+$ & $81.5 \%$ & $(822 / 1009)$ & $2.45(1.50-4.00)$ \\
\hline $25-29$ & $76.7 \%$ & $(434 / 566)$ & $4.77(2.96-7.67)$ \\
\hline $18-24$ & $69.6 \%$ & $(429 / 616)$ & $3.68(2.22-6.11)$ \\
\hline \multicolumn{4}{|l|}{ Age and fishing occupation } \\
\hline $30+$ and involved in fishing & $81.3 \%$ & $(414 / 509)$ & $3.26(1.80-5.90)$ \\
\hline 25-29 and involved in fishing & $78.5 \%$ & $(226 / 288)$ & $4.61(2.40-8.85)$ \\
\hline $18-24$ and involved in fishing & $73.4 \%$ & $(177 / 241)$ & $4.02(1.92-8.43)$ \\
\hline \multicolumn{4}{|l|}{ Age and alcohol drinking } \\
\hline $30+$ and drinks alcohol & $79.6 \%$ & $(460 / 578)$ & $3.34(1.89-5.89)$ \\
\hline 25-29 and drinks alcohol & $78.1 \%$ & $(234 / 311)$ & $7.67(4.62-12.7)$ \\
\hline 18-24 and drinks alcohol & $67.5 \%$ & $(183 / 271)$ & $5.67(3.14-10.2)$ \\
\hline \multicolumn{4}{|c|}{ Age, fishing and alcohol drinking } \\
\hline 30+, fishing and alcohol use & $79.9 \%$ & $(243 / 304)$ & $3.57(1.70-7.49)$ \\
\hline 25-29, fishing and alcohol use & $83.1 \%$ & $(138 / 166)$ & $6.77(3.39-13.5)$ \\
\hline 18-24, fishing and alcohol use & $72.6 \%$ & $(85 / 117)$ & $4.99(1.87-13.3)$ \\
\hline
\end{tabular}

high retention rates $\sim 80 \%$ regardless of whether they were engaged in actual fishing and or alcohol drinking. In this age-group however, the HIV incidence rate ranges between 2.45 and 3.57 per 100 pyar. For every combination of risk factors, HIV incidence was highest in age group of 25-29 years, ranging between 4.61 and $7.67 / 100$ pyar. In this same age group, retention rates between 78.5 - 83.1\% were observed. For every combination of risk factors, the lowest retention rate was among 18-24 year old participants.

\section{Willingness to participate in future HIV vaccine trials} Overall WTP was 89.1\% (1953/2191) and was higher in men than women $(91.2 \%$ vs $87.3 \%, p=0.004)$ and among island communities relative to lakeshore ones (90.4\% vs $85.8 \%, p=0.004$ ) (data not shown). We assessed the factors associated with lack of WTP (unwillingness to participate in future vaccine trials). As shown in Table 3, adjusted predictors of lack of WTP were sex, duration of stay in community and alcohol consumption. Lack of WTP was significantly higher among women than men [adj.OR $=1.51$ (95\% CI, 1.14- 2.00)] and among participants who had stayed in fishing communities for 10 or more years relative to those with less than one year [adj.OR $=1.78$ (95\% CI, 1.11 - 2.88)]. However, particpants who drink alcohol were less likely to lack WTP than nondrinkers [adj.OR = 0.74 (95\% CI, 0.56 - 0.98)] i.e., alcohol drinkers were more willing to participate.

\section{Discussion}

Our assessment indicates that fishing communities around Lake Victoria, Uganda, are potential populations for future HIV vaccine efficacy studies. In these communities we found an overall HIV-1 incidence rate of 3.39/ 100 pyar, a retention rate of $77 \%$, and WTP of $89.3 \%$. The overall incidence rate in this fishing community general population is about 4-5 times higher than that estimated for the national general population of Uganda [28] and 3 times higher than the rate observed in some long term cohorts in Uganda [40,41]. Some sub-groups in these fishing communities have incidence rates as high as $7.7 / 100$ pyar [27]. Other population groups in Uganda with comparable levels of HIV incidence include female sex workers and long distance truck drivers [23,25,26] which are highly selected and gender skewed groups, making it difficult to generalize findings from these populations.

Contrary to the belief that fisher folk are difficult to retain given their mobile nature, we were able to retain $77 \%$ at a 12 month inter-survey interval using passive follow up. This result is very encouraging in that with active follow up at shorter intervals such as those in a vaccine efficacy trials, retention rate is expected to be much higher than that observed in this study. Retention was higher among participants who had stayed for more than one year in the communities which may imply that recent migrants tend to be less stable and may cause challenges in follow up studies. The retention rate we found in this general population of fishing communities 
Table 3 Multivariable analysis of factors associated with lack of willingness to participate (WTP) in hypothetical HIV vaccine trials

\begin{tabular}{|c|c|c|c|c|c|}
\hline & \multicolumn{2}{|c|}{ WTP } & \multicolumn{3}{|c|}{ Odds ratio of lack of WTP } \\
\hline & Yes & No & Crude & Adjusted & P- value \\
\hline & No. (\%) & No. (\%) & $(95 \% \mathrm{Cl})$ & $(95 \% \mathrm{Cl})$ & \\
\hline All Participants & $1953(89.1)$ & $238(10.9)$ & & & \\
\hline \multicolumn{6}{|l|}{ Sex } \\
\hline Male & $1007(91.1)$ & $99(8.9)^{\dagger+}$ & 1 (Ref) & 1 (Ref) & \\
\hline Female & $946(87.2)$ & $139(12.8)$ & $1.49(1.14-1.96)$ & $1.51(1.14-2.00)$ & $0.004^{+\dagger}$ \\
\hline \multicolumn{6}{|l|}{ Age at enrolment (years) } \\
\hline $30+$ & $896(88.8)$ & $113(11.2)$ & 1 (Ref) & - & \\
\hline $25-29$ & $509(89.9)$ & $57(10.1)$ & $0.89(0.63-1.24)$ & - & \\
\hline $18-24$ & $548(89.0)$ & $68(11.0)$ & $0.98(0.71-1.35)$ & - & \\
\hline \multicolumn{6}{|l|}{ Religion } \\
\hline Pentecostal/Evangelical & $169(85.8)$ & $28(14.2)^{\dagger+}$ & 1 (Ref) & - & \\
\hline Roman Catholic & $801(90.0)$ & $89(10.0)$ & $0.67(0.42-1.06)$ & - & \\
\hline Protestant/Anglican & $546(91.0)$ & $54(9.0)$ & $0.60(0.37-0.97)$ & - & \\
\hline Moslem & $361(85.8)$ & $60(14.2)$ & $1.00(0.62-1.63)$ & - & \\
\hline Other" & $76(91.6)$ & $7(8.4)$ & $0.55(0.23-1.33)$ & - & \\
\hline \multicolumn{6}{|l|}{ Ethnicity/tribe } \\
\hline Non-Muganda & $1080(90.2)$ & $117(9.8)$ & 1 (Ref) & - & \\
\hline Muganda & $873(87.8)$ & $121(12.2)$ & $1.28(0.98-1.67)$ & - & \\
\hline \multicolumn{6}{|l|}{ Occupation } \\
\hline Fishing/Fishing related & $947(91.2)$ & $91(8.8)$ & 1 (Ref) & - & \\
\hline Trade/Business & $196(87.9)$ & $27(12.1)$ & $1.43(0.91-2.26)$ & - & \\
\hline Bar/Lodge/Restaurant & $225(87.6)$ & $32(12.4)$ & $1.48(0.96-2.27)$ & - & \\
\hline Farming & $114(87.7)$ & $16(12.3)$ & $1.46(0.83-2.57)$ & - & \\
\hline Others $^{t}$ & $309(87.5)$ & $44(12.5)$ & $1.48(1.01-2.17)$ & - & \\
\hline Housewife & $162(85.3)$ & $28(14.7)$ & $1.79(1.14-2.83)$ & - & \\
\hline \multicolumn{6}{|l|}{ Marital status } \\
\hline Married monogamous & $819(88.7)$ & $104(11.3)$ & 1 (Ref) & & \\
\hline Married polygamous & $378(89.4)$ & $45(10.6)$ & $0.94(0.65-1.36)$ & - & \\
\hline Not currently married & $450(89.1)$ & $55(10.9)$ & $0.96(0.68-1.36)$ & & \\
\hline Never married & $306(90.0)$ & $34(10.0)$ & $0.87(0.58-1.32)$ & - & \\
\hline \multicolumn{6}{|c|}{ Duration in community (years) } \\
\hline Less than 1 & $357(90.6)$ & $37(9.4)^{\dagger}$ & 1 (Ref) & 1 (Ref) & \\
\hline 1 to 4 & 737 (89.6) & $86(10.4)$ & $1.12(0.75-1.69)$ & $1.17(0.78-1.77)$ & 0.43 \\
\hline 5 to 10 & $597(89.2)$ & $72(10.8)$ & $1.16(0.77-1.77)$ & $1.26(0.83-1.93)$ & 0.28 \\
\hline More than 10 & $262(85.9)$ & $43(14.1)$ & $1.58(0.99-2.53)$ & $1.78(1.11-2.88)$ & 0.018 \\
\hline \multicolumn{6}{|l|}{ Alcohol consumption } \\
\hline No & $1104(87.9)$ & $152(12.1)^{\dagger \dagger}$ & 1 (Ref) & 1 (Ref) & \\
\hline Yes & 849 (90.8) & $86(9.2)$ & $0.70(0.53-0.91)$ & $0.74(0.56-0.98)$ & 0.04 \\
\hline
\end{tabular}

${ }^{\overline{9}}$ Seventh Day Adventist/Traditional, ${ }^{+\dagger}$ Statistically significant at $\mathrm{p}<0.05,{ }^{\dagger}$ Borderline statistical significance at $\mathrm{p}<0.05,{ }^{\mathrm{t}}$ Construction/Mechanic/Government/Clerical.

is consistent with that found among fisherfolk that were screened for high risk behaviours (76\%) [24] and in other population-based studies in Uganda [42,43]. In a combined analysis of retention and incidence rates participants aged 30 or more years had retention rates $\sim 80 \%$ with incidence rates ranging between 2.45 and 3.57 per 100 pyar while those aged $25-29$ years had the highest incidence rates (4.61 - 7.67/100 pyar) and 
high retention rates between $78.5-83.1 \%$. Retention was lowest among young adults aged $18-24$ years. This finding appears to indicate that among fishing communities around Lake Victoria, Uganda, maximization of both HIV incidence and retention occurs among participants aged 25-29 years. In actual vaccine efficacy trials, efficient recruitment and retention of large numbers of participants is crucial in for the success of the study $[12,13]$. Our observed retention rate of $77 \%$ could be improved by methods such as frequent participant contact and active tracing, shorter follow up intervals, and use of mobile telephone technology which have improved retention in other high risk and marginalized population groups [44,45]. However, given the unique characteristics of fishing communities it would be prudent to evaluate the effectiveness of those strategies in enhancing retention before adopting them in actual trials.

Although WTP assessed hypothetically does not necessarily reflect levels participation in a real trial [46], we found that only $10.9 \%$ of fisherfolk expressed lack of willingness to participate in future HIV vaccine trials. Lack of WTP was significantly higher among women and folks with 10 or more years of stay in communities. A similar study in Masaka district, southern Uganda, also found higher levels of lack of WTP among women than men. In that study the requirement to delay pregnancy during the trial and shortly thereafter was associated with lower levels of WTP [31]. Since both women and men will be needed to participate in future HIV vaccine efficacy trials, it is important to address issues that may lead to women's unwillingness to participate in these trials. We also found that lack of WTP was significantly lower among alcohol drinkers yet alcohol drinking is one of major risk factors for HIV infection in this population. This finding indicates that it may not be difficult to recruit "high risk" fisherfolk in future vaccine efficacy trials. However, lack of WTP was significantly higher in person who had stayed for more than 10 years in fishing communities yet retention was much better in same group. At this time we do not know the reasons for this discrepancy but plans to investigate it are underway.

The strength of this study is that it was conducted in a randomly selected general population of fishing communities. We note that the study is not without limitations. First, a long inter-survey period of 12 months does not represent the shorter follow up intervals typically seen in the early period of vaccine trials. Second, the hypothetical assessment of WTP does not necessarily reflect actual willingness observed in real vaccine trials [46]. Third, retention rates were assessed at one follow up visit (due to the design of the study) and as such represent a cross-sectional assessment at the one follow up visit.

\section{Conclusions}

The finding of high HIV incidence, good retention rates, and high WTP, indicates that fishing communities are potential populations for HIV prevention efficacy trials including vaccines and combination interventions.

UVRI-IAVI Research Team includes Brian Kabuubi, Annie Marie Namumiina, Wangira Denis, Marion Namuleme, Polly Mukiibi, Michael Ssenkayi, Kiwagu Humphrey, Kagolo Edward, Brian Matovu, and Ali Olega.

\section{Competing interests}

The authors declare that they have no competing interests.

\section{Authors' contributions}

Contributors NK: Corresponding author; contributed to the study design, application for funding, general coordination of the study, data analysis and interpretation, manuscript writing, submission and final versions. JM: co-author; contributed to study coordination, interpretation of results and manuscript writing. AN: co-author; coordinated data management, and contributed to analysis and interpretation of results. MW: co-author; contributed to field implemetation of study and manuscript writing. AN: co-author; contributed to coordination of the study including regualtory aspects, interpreation of results and manuscript writing. PKK: co-author; coordinated laboratory testing of specimens, and contributed to manuscript writing. EM: co-author; contributed to laboratory testing of specimens and manuscript writing. JS: co-author; contributed to statistical analysis and interpretation of results, and manuscript writing. $A B$; co-author; contributed to the study design and manuscript writing. AS: co-author; coordinated the field implemetation of study, and participated in manuscript writing, and interpretation of results. All authors read and approved the final manuscript.

\section{Acknowledgments}

This work was made possible in part by the generous support of the American people through the United States Agency for International Development (USAID) through the International AIDS Vaccine Initiative, USA, and the Training Health Researchers into Vocational Excellence in East Africa Project (THRiVE), Grant Number 087540 of Wellcome Trust, UK, and the Canada-Africa Prevention Trials Network (CAPTN) grant number 1063357001. The authors greatly appreciated the study participants for providing the data, the Science and Ethics Committee of UVRI for reviewing the study, and the UVRI-IAVI HIV Vaccine Program research team for implementing the study. We thank the two reviewers and Leslie Elizabeth Nielsen for their insightful comments on the manuscript. The contents are the responsibility of the study authors and do not necessarily reflect the views of USAID or the United States Government, or any of other agencies that supported this work.

\section{Author details}

'Uganda Virus Research Institute-International AIDS Vaccine Initiate HIV Vaccine Program, Entebbe, Uganda. ${ }^{2}$ International AIDS Vaccine Initiative (IAVI), New York, USA. ${ }^{3}$ Department of Epidemiology and Biostatistics, College of Health Sciences, School of Public Health, Makerere University, Kampala, Uganda.

Received: 9 July 2014 Accepted: 18 September 2014 Published: 22 September 2014

\section{References}

1. Gray RH, Kigozi G, Serwadda D, Makumbi F, Watya S, Nalugoda F, Kiwanuka N, Moulton LH, Chaudhary MA, Chen MZ, Sewankambo NK, WabwireMangen F, Bacon MC, Williams CF, Opendi P, Reynolds SJ, Laeyendecker O, Quinn TC, Wawer MJ: Male circumcision for HIV prevention in men in Rakai, Uganda: a randomised trial. Lancet 2007, 369:657-666.

2. Auvert B, Taljaard D, Lagarde E, Sobngwi-Tambekou J, Sitta R, Puren A: Randomized, controlled intervention trial of male circumcision for 
reduction of HIV infection risk: the ANRS 1265 Trial. PLoS Med 2005, 2:e298.

3. Donnell D, Baeten JM, Kiarie J, Thomas KK, Stevens W, Cohen CR, McIntyre J, Lingappa JR, Celum C: Heterosexual HIV-1 transmission after initiation of antiretroviral therapy: a prospective cohort analysis. Lancet 2010, 375:2092-2098.

4. Baeten JM, Donnell D, Ndase P, Mugo NR, Campbell JD, Wangisi J, Tappero JW, Bukusi EA, Cohen CR, Katabira E, Ronald A, Tumwesigye E, Were E, Fife $\mathrm{KH}$, Kiarie J, Farquhar C, John-Stewart G, Kakia A, Odoyo J, Mucunguzi A, Nakku-Joloba E, Twesigye R, Ngure K, Apaka C, Tamooh H, Gabona F, Mujugira A, Panteleeff D, Thomas KK, Kidoguchi L, et al: Antiretroviral prophylaxis for HIV prevention in heterosexual men and women. N Engl J Med 2012, 367:399-410 doi:10.1056/NEJMoa1108524.

5. Thigpen MC, Kebaabetswe PM, Paxton LA, Smith DK, Rose CE, Segolodi TM, Henderson FL, Pathak SR, Soud FA, Chillag KL, Mutanhaurwa R, Chirwa LI, Kasonde M, Abebe D, Buliva E, Gvetadze RJ, Johnson S, Sukalac T, Thomas VT, Hart C, Johnson JA, Malotte CK, Hendrix CW, Brooks JT: Antiretroviral preexposure prophylaxis for heterosexual HIV transmission in Botswana. N Engl J Med 2012, 367:423-434 doi:10.1056/NEJMoa1110711.

6. Thigpen MC, Rose CE, Paxton LA: Antiretroviral preexposure prophylaxis for HIV prevention. N Engl J Med 2013, 368:82-83 doi:10.1056/NEJMC 1210464.

7. Grant RM, Lama JR, Anderson PL, McMahan V, Liu AY, Vargas L, Goicochea P, Casapia M, Guanira-Carranza JV, Ramirez-Cardich ME, Montoya-Herrera O, Fernandez T, Veloso VG, Buchbinder SP, Chariyalertsak S, Schechter M, Bekker LG, Mayer KH, Kallas EG, Amico KR, Mulligan K, Bushman LR, Hance R, Ganoza C, Defechereux P, Postle B, Wang F, McConnell JJ, Zheng JH, Lee J, et al: Preexposure chemoprophylaxis for HIV prevention in men who have sex with men. N Engl J Med 2010, 363:2587-2599 doi:10.1056/NEJMoa1011205.

8. Cohen MS, McCauley M, Gamble TR: HIV treatment as prevention and HPTN 052. Curr Opin HIV AIDS 2012, 7:99-105 doi:10.1097/COH.0b013e3 $2834 f 5 c f 2$.

9. El-Sadr WM, Coburn BJ, Blower S: Modeling the impact on the HIV epidemic of treating discordant couples with antiretrovirals to prevent transmission. AIDS 2011, 25:2295-2299 doi:10.1097/QAD.0b013e328 $34 \mathrm{c} 4 \mathrm{c} 22$

10. El-Sadr WM, Serwadda DM, Sista N, Cohen MS: HIV prevention: great achievements, more challenges ahead. J Acquir Immune Defic Syndr 2013, 63(Suppl 2):S115-S116.

11. UNAIDS: UNAIDS Report 2012. Global report: UNAIDS report on the global AIDS epidemic 2012. Geneva: Joint United Nations Programme on HIV/AIDS; 2012. http://www.unaids.org/en/media/unaids/contentassets/documents/ epidemiology/2012/gr2012/20121120_UNAIDS_Global_Report_2012_ with_annexes_en.pdf.

12. Smit J, Middelkoop K, Myer L, Lindegger G, Swartz L, Seedat S, Tucker T, Wood R, Bekker LG, Stein DJ: Socio-behaviour challenges to phase III HIV vaccine trials in Sub-Saharan Africa. Afr Health Sci 2005, 5:198-206 doi:10.5555/afhs.2005.5.3.198.

13. Grinstead OA: Social and behavioral issues in phase III HIV preventive vaccine trials. AIDS 1995, 9(Suppl A):S245-S250.

14. Hammer SM, Sobieszczyk ME, Janes H, Karuna ST, Mulligan MJ, Grove D, Koblin BA, Buchbinder SP, Keefer MC, Tomaras GD, Frahm N, Hural J, Anude C, Graham BS, Enama ME, Adams E, DeJesus E, Novak RM, Frank I, Bentley C, Ramirez S, Fu R, Koup RA, Mascola JR, Nabel GJ, Montefiori DC, Kublin J, McElrath MJ, Corey L, Gilbert PB: Efficacy trial of a DNA/rAd5 HIV-1 preventive vaccine. N Engl J Med 2013, 369:2083-2092 doi:10.1056/ NEJMoa1310566.

15. Flynn NM, Forthal DN, Harro CD, Judson FN, Mayer KH, Para MF: Placebocontrolled phase 3 trial of a recombinant glycoprotein 120 vaccine to prevent HIV-1 infection. J Infect Dis 2005, 191:654-665.

16. Pitisuttithum $P$, Gilbert $P$, Gurwith M, Heyward W, Martin M, van GF, Hu D, Tappero JW, Choopanya K: Randomized, double-blind, placebo-controlled efficacy trial of a bivalent recombinant glycoprotein 120 HIV-1 vaccine among injection drug users in Bangkok, Thailand. J Infect Dis 2006, 194:1661-1671.

17. Buchbinder SP, Mehrotra DV, Duerr A, Fitzgerald DW, Mogg R, Li D, Gilbert PB, Lama JR, Marmor M, Del RC, McElrath MJ, Casimiro DR, Gottesdiener KM, Chodakewitz JA, Corey L, Robertson MN: Efficacy assessment of a cell-mediated immunity HIV-1 vaccine (the Step Study): a double-blind, randomised, placebo-controlled, test-of-concept trial. Lancet 2008 372:1881-1893.
18. McElrath MJ, De Rosa SC, Moodie Z, Dubey S, Kierstead L, Janes H, Defawe OD, Carter DK, Hural J, Akondy R, Buchbinder SP, Robertson MN, Mehrotra DV, Self SG, Corey L, Shiver JW, Casimiro DR: HIV-1 vaccine-induced immunity in the test-of-concept Step Study: a case-cohort analysis. Lancet 2008, 372:1894-1905.

19. Gray GE, Allen M, Moodie Z, Churchyard G, Bekker LG, Nchabeleng M, Mlisana K, Metch B, de BG, Latka MH, Roux S, Mathebula M, Naicker N, Ducar C, Carter DK, Puren A, Eaton N, McElrath MJ, Robertson M, Corey L, Kublin JG: Safety and efficacy of the HVTN 503/Phambili study of a clade-B-based HIV-1 vaccine in South Africa: a double-blind, randomised, placebo-controlled test-of-concept phase 2b study. Lancet Infect Dis 2011, 11:507-515

20. Rerks-Ngarm S, Pitisuttithum P, Nitayaphan S, Kaewkungwal J, Chiu J, Paris R, Premsri N, Namwat C, de SM, Adams E, Benenson M, Gurunathan S, Tartaglia J, McNeil JG, Francis DP, Stablein D, Birx DL, Chunsuttiwat S, Khamboonruang C, Thongcharoen P, Robb ML, Michael NL, Kunasol P, Kim $J H$ : Vaccination with ALVAC and AIDSVAX to prevent HIV-1 infection in Thailand. N Engl J Med 2009, 361:2209-2220.

21. NIH: Clinical Trials Registry. 2014. www.clinicaltrials.gov.

22. Fast PE, Kaleebu P: HIV vaccines: current status worldwide and in Africa. AIDS 2010, 24(Suppl 4):S50-S60

23. Chersich MF, Luchters S, Ntaganira I, Gerbase A, Lo YR, Scorgie F, Steen R: Priority interventions to reduce HIV transmission in sex work settings in sub-Saharan Africa and delivery of these services. J Int AIDS Soc 2013, 16:17980.

24. Seeley J, Nakiyingi-Miiro J, Kamali A, Mpendo J, Asiki G, Abaasa A, De BJ, Nielsen L, Kaleebu P: High HIV incidence and socio-behavioral risk patterns in fishing communities on the shores of Lake Victoria, Uganda. Sex Transm Dis 2012, 39:433-439.

25. Gysels M, Pool R, Bwanika K: Truck drivers, middlemen and commercial sex workers: AIDS and the mediation of sex in south west Uganda. AIDS Care 2001, 13:373-385.

26. Bwayo J, Plummer F, Omari M, Mutere A, Moses S, Ndinya-Achola J, Velentgas $P$, Kreiss J: Human immunodeficiency virus infection in long-distance truck drivers in east Africa. Arch Intern Med 1994, 154:1391-1396.

27. Kiwanuka N, Ssetaala A, Nalutaaya A, Mpendo J, Wambuzi M, Nanvubya A, Sigirenda S, Kitandwe PK, Nielsen LE, Balyegisawa A, Kaleebu P, Nalusiba J, Sewankambo NK: High Incidence of HIV-1 Infection in a General Population of Fishing Communities around Lake Victoria, Uganda. PLoS One 2014, 9:e94932.

28. Kim AA, Hallett T, Stover J, Gouws E, Musinguzi J, Mureithi PK, Bunnell R, Hargrove J, Mermin J, Kaiser RK, Barsigo A, Ghys PD: Estimating HIV incidence among adults in Kenya and Uganda: a systematic comparison of multiple methods. PLoS One 2011, 6:e17535 doi:10.1371/journal. pone.0017535.

29. Kwena ZA, Camlin CS, Shisanya CA, Mwanzo I, Bukusi EA: Short-term mobility and the risk of HIV infection among married couples in the fishing communities along Lake Victoria, Kenya. PLoS One 2013, 8:e54523.

30. Nunan F, Luomba J, Lwenya C, Yongo E, Odongkara K, Ntambi B: Finding space for participation: fisherfolk mobility and co-management of Lake Victoria fisheries. Environ Manage 2012, 50:204-216 doi:10.1007/s00267012-9881-y

31. Asiki G, Abaasa A, Ruzagira E, Kibengo F, Bahemuka U, Mulondo J, Seeley J, Bekker LG, Delany S, Kaleebu P, Kamali A: Willingness to participate in HIV vaccine efficacy trials among high risk men and women from fishing communities along Lake Victoria in Uganda. Vaccine 2013, 31:5055-5061.

32. Camlin CS, Kwena ZA, Dworkin SL: Jaboya vs. jakambi: Status, negotiation, and HIV risks among female migrants in the "sex for fish" economy in Nyanza Province, Kenya. AIDS Educ Prev 2013, 25:216-231 doi:10.1521/ aeap.2013.25.3.216

33. MacPherson EE, Sadalaki J, Njoloma M, Nyongopa V, Nkhwazi L, Mwapasa V, Lalloo DG, Desmond N, Seeley J, Theobald S: Transactional sex and HIV: understanding the gendered structural drivers of HIV in fishing communities in Southern Malawi. J Int AIDS Soc 2012, 15(Suppl 1):1-9.

34. Smolak A: A meta-analysis and systematic review of HIV risk behavior among fishermen. AIDS Care 2014, 26:282-291 doi:10.1080/09540121.2013. 824541 .

35. Kiwanuka N, Ssetaala A, Mpendo J, Wambuzi M, Nanvubya A, Sigirenda S, Nalutaaya A, Kato P, Nielsen L, Kaleebu P, Nalusiba J, Sewankambo NK: High 
HIV-1 prevalence, risk behaviours, and willingness to participate in HIV vaccine trials in fishing communities on Lake Victoria, Uganda. J Int AIDS Soc 2013, 16:18621

36. Skov T, Deddens J, Petersen MR, Endahl L: Prevalence proportion ratios: estimation and hypothesis testing. Int J Epidemiol 1998, 27:91-95.

37. Barros AJ, Hirakata VN: Alternatives for logistic regression in cross-sectional studies: an empirical comparison of models that directly estimate the prevalence ratio. BMC Med Res Methodol 2003, 3:21.

38. Zeger SL, Liang KY, Albert PS: Models for longitudinal data: a generalized estimating equation approach. Biometrics 1988, 44:1049-1060.

39. Hosmer DW, Lemeshow S: Applied Logistic Regression. 2nd edition. Scientific, Technical and Medical Division, 605 Third Avenue, New York, N.Y: John Wiley \& Sons, Inc; 2000:10158-0012.

40. Kagaayi J, Gray RH, Whalen C, Fu P, Neuhauser D, McGrath JW, Sewankambo NK, Serwadda D, Kigozi G, Nalugoda F, Reynolds SJ, Wawer MJ, Singer ME: Indices to Measure Risk of HIV Acquisition in Rakai, Uganda. PLoS One 2014, 9:e92015.

41. Ruzagira E, Wandiembe S, Abaasa A, Levin J, Bwanika A, Bahemuka U, Price MA, Kamali A: Prevalence and incidence of HIV in a rural community-based HIV vaccine preparedness cohort in Masaka, Uganda. PLoS One 2011, 6:e20684.

42. Wawer MJ, Sewankambo NK, Serwadda D, Quinn TC, Paxton LA, Kiwanuka N, Wabwire-Mangen F, Li C, Lutalo T, Nalugoda F, Gaydos CA, Moulton LH, Meehan MO, Ahmed S, Gray RH: Control of sexually transmitted diseases for AIDS prevention in Uganda: a randomised community trial. Rakai Project Study Group. Lancet 1999, 353:525-535.

43. Kamali A, Kinsman J, Nalweyiso N, Mitchell K, Kanyesigye E, Kengeya-Kayondo JF, Carpenter LM, Nunn A, Whitworth JA: A community randomized controlled trial to investigate impact of improved STD management and behavioural interventions on HIV incidence in rural Masaka, Uganda: trial design, methods and baseline findings. Trop Med Int Health 2002, 7:1053-1063.

44. Etcheverry MF, Evans JL, Sanchez E, Mendez-Arancibia E, Merono M, Gatell $\mathrm{JM}$, Page K, Joseph J: Enhanced retention strategies and willingness to participate among hard-to-reach female sex workers in Barcelona for HIV prevention and vaccine trials. Hum Vaccin Immunother 2013, 9:420-429.

45. McCallum GB, Versteegh LA, Morris PS, Mckay CC, Jacobsen NJ, White AV, D'Antoine HA, Chang AB: Mobile phones support adherence and retention of indigenous participants in a randomised controlled trial: strategies and lessons learnt. BMC Public Health 2014, 14:622.

46. Buchbinder SP, Metch B, Holte SE, Scheer S, Coletti A, Vittinghoff E: Determinants of enrollment in a preventive HIV vaccine trial: hypothetical versus actual willingness and barriers to participation. J Acquir Immune Defic Syndr 2004, 36:604-612.

\section{doi:10.1186/1471-2458-14-986}

Cite this article as: Kiwanuka et al:: An assessment of fishing communities around Lake Victoria, Uganda, as potential populations for future HIV vaccine efficacy studies: an observational cohort study. BMC Public Health 2014 14:986.

\section{Submit your next manuscript to BioMed Central and take full advantage of:}

- Convenient online submission

- Thorough peer review

- No space constraints or color figure charges

- Immediate publication on acceptance

- Inclusion in PubMed, CAS, Scopus and Google Scholar

- Research which is freely available for redistribution 